\title{
Dispersal patterns of shrimp larvae and postlarvae of the genus Solenocera
}

\author{
Patrones de dispersión de larvas y postlarvas de camarón del género Solenocera \\ Mario A. Gómez ${ }^{1}$ and Adolfo Gracia ${ }^{1}$ \\ ${ }^{1}$ Instituto de Ciencias del Mar y Limnología. Universidad Nacional Autónoma de México (UNAM) \\ Apartado postal 70-305, México 04510. D. F., México \\ mgomez@mar.icmyl.unam.mx
}

Resumen.- Se analiza la abundancia y los procesos de dispersión de los primeros estadios larvales y postlarvales de Solenocera spp. (Burkenroad, 1939). Los datos obtenidos se basaron en tres campañas oceanográficas realizadas en el sur de la bahía de Campeche, México, durante el verano y otoño de 1993 y primavera de 1994. El verano fue el período de mayor abundancia con una densidad larvaria promedio de protozoeas, mysis y postlarvas correspondientes a 19,8; 22,1 y 1,9 organismos $100 \mathrm{~m}^{-3}$, respectivamente. Las larvas presentaron, en general, un típico patrón diario de migración. Ellas se desplazaron de zonas de mayor profundidad hacia la superficie en la noche, mientras que durante el día éstas tendieron a dirigirse hacia las profundidades. Las protozoeas se distribuyeron con mayor frecuencia en los niveles superficiales mientras que las mysis y postlarvas fueron capturadas en mayor número en los niveles más profundos. En general, las protozoeas y mysis se distribuyeron en profundidades sobre la termoclina, haloclina y picnoclina. La disponibilidad de alimento parece ser el principal factor para determinar la distribución vertical de Solenocera spp.

Palabras clave: Crustacea, plancton, distribución, abundancia estacional, migración vertical

\begin{abstract}
The abundance and the dispersal processes during the larval and postlarval stages of Solenocera spp. (Burkenroad, 1939) is analyzed. Data were collected in three oceanographic cruises performed in the south of the Campeche Bay, Mexico, during summer and autumn 1993 and spring 1994. Summer was the period with the highest abundance with an average larval density of protozoea, mysis, and postlarvae of 19.8, 22.1, and 1.9 organisms per $100 \mathrm{~m}^{3}$ respectively. In general, larvae presented a typical daily migration pattern. They moved from deep areas to the surface at night, whereas during the day they tended to move downwards. Protozoeae were most frequently distributed at the surface levels, whereas mysis were rather caught at deeper levels. In general, protozoea and mysis were distributed at depths above the thermocline, halocline and pycnocline. Food availability seems to be the most important factor determining Solenocera spp. vertical distribution.
\end{abstract}

Keywords: Crustacea, plankton, distribution, seasonal abundance, vertical migration

Shrimps, which are one of the most important fishery resource from Mexico, are comprised of species whose commercial value varies according to their size and catch, such as Litopenaeus setiferus (Linnaeus, 1767), Farfantepenaeus aztecus Ives, 1891, and Farfantepenaeus duorarum Burkenroad, 1939, in the Gulf of Mexico. During trawl operations, other smallsized species of lesser value are caught which are not so important in terms of relative abundance. However, these species among which are those of the genus Solenocera represent a relevant part of the food web in the marine ecosystem and are a relatively abundant component in the plankton community. In the south of 
the Gulf of Mexico, three species of the genus Solenocera have been reported (Solenocera vioscai Burkenroad, 1934; Solenocera necopina Burkenroad, 1939 and Solenocera atlantidis Burkenroad, 1939). Solenocera vioscai is the most abundant and represents more than $98 \%$ of Solenocera genus (Vázquez-Bader \& Gracia 1994), so it could be expected that a large proportion of the larvae belongs to this species. The goal of this study is to analyze the planktonic dispersal mechanisms of the Solenocera genus and to determine the temporal variations in the distribution and abundance during the first life stages of these organisms, associated with local current patterns, temperature, salinity, and photo period.

\section{Material and methods}

The present study was part of the MOPEED project (Monitoring of pre-recruits of estuarine-dependent species, benthic communities, and internal tides in the south of the Gulf of Mexico) from the Instituto de Ciencias del Mar y Limnología, UNAM, and included samples from three oceanographic cruises carried out on board the R/V "Justo Sierra", during three seasons: summer (August 13-22, 1993) and autumn (November 4-14, 1993), and spring (May 22-30, 1994).

The study area is located in the southern portion of the Gulf of Mexico between $18^{\circ}$ and $20^{\circ} \mathrm{N} ; 91^{\circ}$ and $94^{\circ} \mathrm{W}$, and comprises parts of the states of Tabasco and Campeche continental shelf (from the Machona Lagoon to the most eastern portion of the Términos Lagoon (Fig. 1).

The sampling grid included four perpendicular transects to the coast located near the main delta systems of the study area, i.e., from the Machona Lagoon in the state of Tabasco to the Términos Lagoon in the state of Campeche, sampling in waters 10 to 200 $\mathrm{m}$ depth over the continental shelf (Fig. 1). Zooplankton hauls were performed with opening-closing nets (General Oceanics, model 5100) of $0.75 \mathrm{~m}$ opening diameter and $500 \mu \mathrm{m}$ mesh size provided with torpedotype digital flow meters to estimate the filtered water volume. Sampling depth varied from 2 to $100 \mathrm{~m}$, with 15 min duration for each cast. The ship towing velocity was 2 to 3 knots during sampling.

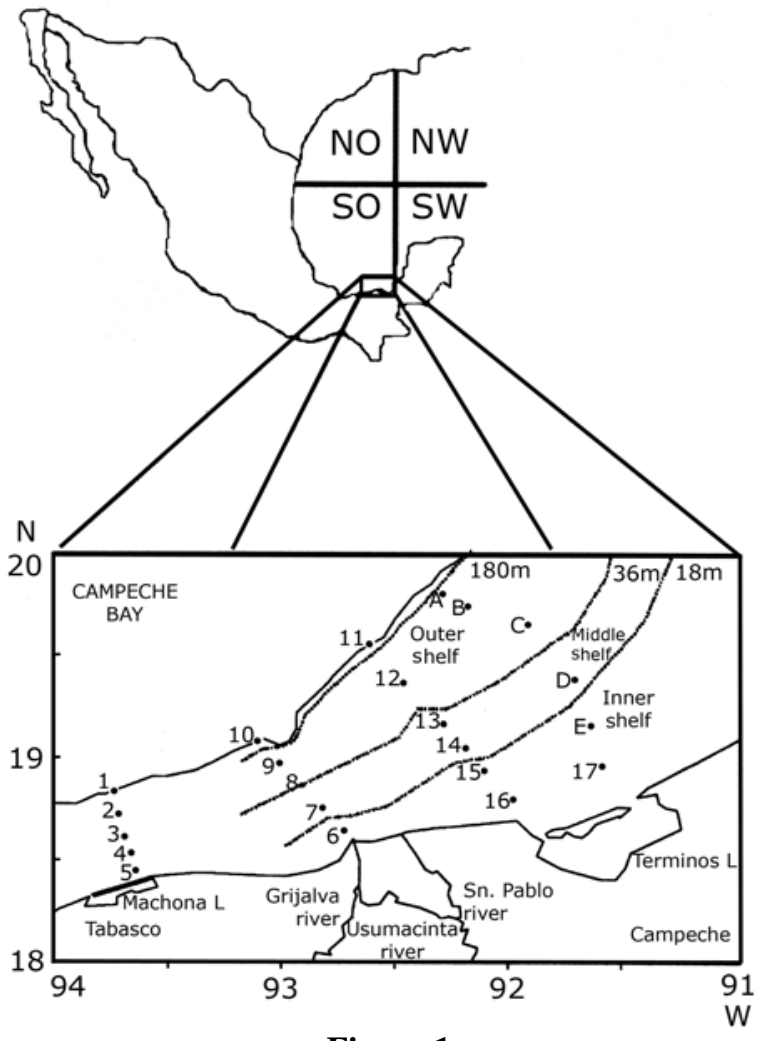

Figure 1

Study area and zooplankton sampling locations in the southwestern Gulf of Mexico

Área de estudio y estaciones de muestreo de zooplancton en el suroeste del Golfo de México

The number of nets (2-5) used in each zooplankton cast varied as a function of the sampling location depths (2, 10, 20, 45 and $100 \mathrm{~m}$ ) and, in some occasions, this procedure was performed in two stages. Onboard the sample was preserved in $4 \%$ formaldehyde neutralized with borated sodium. Once in the laboratory, samples were placed in 70\% alcohol. From the total of samples, larvae of the Solenoceridae family were separated and identified according to the keys reported by Cook (1966) and Subrahmanyam (1971).

The zooplankton abundance of each oceanographic cruise was standardized to the number of Solenocera spp. larvae $100 \mathrm{~m}^{-3}$, according to the equation of Smith \& Richardson (1977). 
In order to analyze the vertical migration of the larvae throughout the water column, the day samples were divided in four groups related with the light intensity. It was though considered that dusk and dawn could be critical for vertical migration pattern, so they were included in the analysis in spite of the lesser duration compared to day and night. Light-intensity groups were done according to the seasonal and latitudinal registers of the Astronomical Applications Department of the U.S. Naval Observatory (http://aa.usno.navy.mil/data/docs/RS): Spring 1994, Day (06:01-18:39 h), Dusk (18:40-19:10 h), Night (19:11-05:29 h) and Dawn (05:30-06:00 h); Summer 1993, Day (06:21-18:33 h), Dusk (18:34-19:14 h), Night (19:15-05:49 h) and Dawn (05:50-06:20 h); Autumn 1993, Day (06:43-17:30 h), Dusk (17:31-18:01 h), Night (18:02-06:11 h) and Dawn (06:12-06:42 h).

Analyses of variance were performed to analyze significant differences among larval densities during the three sampled periods at different depths and day periods.

\section{Results}

Solenocera spp. seasonal abundance

During the three oceanographic cruises, a total of 3,102 Solenocera specimens were caught, corresponding to three planktonic stages (protozoea, mysis, and postlarvae) (Table 1).

The summer 1993 was the period with the highest abundance: 1689 specimens (771 protozoea, 860 mysis, and 58 postlarvae). During the autumn 1993, the total catch was 1044 specimens (568 protozoea, 465 mysis, and 11 postlarvae), whereas spring 1994 was the period of lowest catches, with 369 specimens (250 protozoea, 86 mysis, and 33 postlarvae).
The analysis of variance among seasons (spring, summer, autumn), period of the day (day, dusk, night, and dawn), and depth of sampling (2, 10, 20, 45, and $100 \mathrm{~m}$ ) yielded significant differences among larval densities during the three sampled periods at different depths and during the different periods of the day (different depths $\mathrm{F}_{(5,15)}=10.49 ; \quad P=0.001$; period of the day $\mathrm{F}_{(4,12)}=3.43, P=0.005$; and season, $\mathrm{F}_{(3,9)}=$ $6.44, P=0.003$ )

\section{Vertical distribution of Solenocera spp.}

Spring 1994.- Protozoea larvae were found along the transects located in front of the Machona Lagoon, El Carmen Inlet, and Puerto Real, distributed at all depths sampled. The largest concentrations were found between 2 and $10 \mathrm{~m}$ depth, mainly at transect located in front of the Machona Lagoon (61 to 80 larvae $100 \mathrm{~m}^{-3}$ ) in the state of Tabasco, near the coastline (Fig. 2A). Mysis were found at all transects at depths ranging from 2 to $100 \mathrm{~m}$. The recorded density was similar at the different sampling depths ( 1 to 20 larvae $100 \mathrm{~m}^{-3}$ ) (Fig. 2B). The postlarvae distribution was similar to protozoea and mysis stages, and they were also located at depths of 2 to $100 \mathrm{~m}$, with a density of 1 to 20 larvae $100 \mathrm{~m}^{-3}$ (Fig. 2C). Nonetheless, postlarvae showed a general distribution pattern with protozoea and mysis near surface and postlarvae in deeper waters.

Summer 1993.- Protozoea larvae were recorded in most of the study area, mainly at transects located off Machona Lagoon and El Carmen inlet. The highest protozoea density was found at depths between 2 and $10 \mathrm{~m}$ in front of the El Carmen inlet, with values of 40 and more than 80 larvae $100 \mathrm{~m}^{-3}$. During this season, protozoea larvae were also caught once at depths over $100 \mathrm{~m}$ off the Grijalva-Usumacinta River; however, their abundance was low (1-20 $100 \mathrm{~m}^{-3}$ ) (Fig. 3A).

\section{Table 1}

Total number of Solenocera larvae and postlarvae caught in the different seasons sampled

Número total de larvas y postlarvas de Solenocera capturadas en las diferentes temporadas de muestreo

\begin{tabular}{ccccc}
\hline Season & Protozoea & Mysis & Postlarvae & Total \\
\hline Spring & 250 & 86 & 33 & 369 \\
Summer & 771 & 860 & 58 & 1689 \\
Autumn & 568 & 465 & 11 & 1044 \\
Total & 1589 & 1411 & 102 & 3102 \\
\hline
\end{tabular}




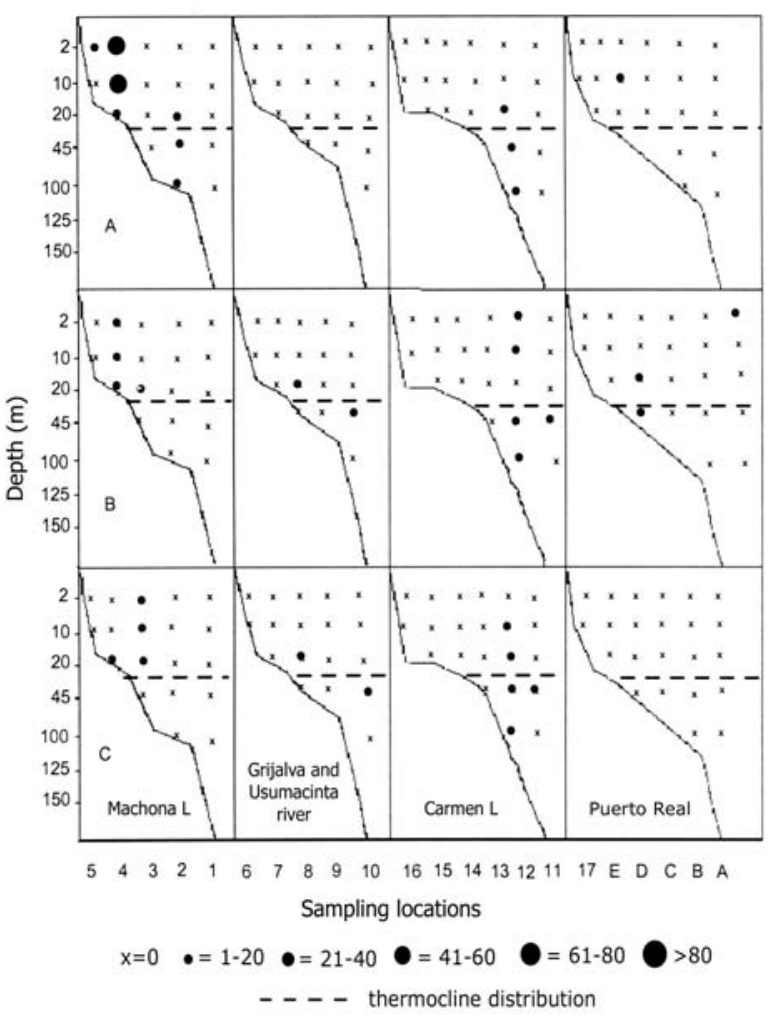

Figure 2

Solenocera larval and postlarval abundance $\left(\mathrm{N}^{\circ} 100 \mathrm{~m}^{-3}\right)$ in the different transects and depth levels. Spring 1994. A) protozoea, B) mysis and C) postlarvae

Abundancia de larvas y postlarvas de Solenocera $\left(\mathrm{N}^{\circ} 100\right.$ $\mathrm{m}^{-3}$ ) en diferentes niveles de profundidad y transectos.

Primavera de 1994. A) protozoea, B) mysis y C) postlarvas

The mysis stage depicted a similar distribution pattern that varied from 2 to $100 \mathrm{~m}$, with zones of larger abundance off El Carmen at $10 \mathrm{~m}$ depth, recording more than 70 larvae $100 \mathrm{~m}^{-3}$ and in front of the Machona Lagoon with 40 to 60 larvae $100 \mathrm{~m}^{-3}$ (Fig. 3B). Postlarvae depicted a low density during the summer ( 1 to 20 larvae $100 \mathrm{~m}^{-3}$ ), and were distributed from 2 to $100 \mathrm{~m}$ depth (Fig. 3C).

Autumn 1993.- Protozoeae were more abundant off the Machona Lagoon and El Carmen. The highest abundances were located between 2 and $45 \mathrm{~m}$ depth. A site with more than 80 larvae $100 \mathrm{~m}^{-3}$ was recorded at $45 \mathrm{~m}$ depth in front of the El Carmen inlet, precisely,

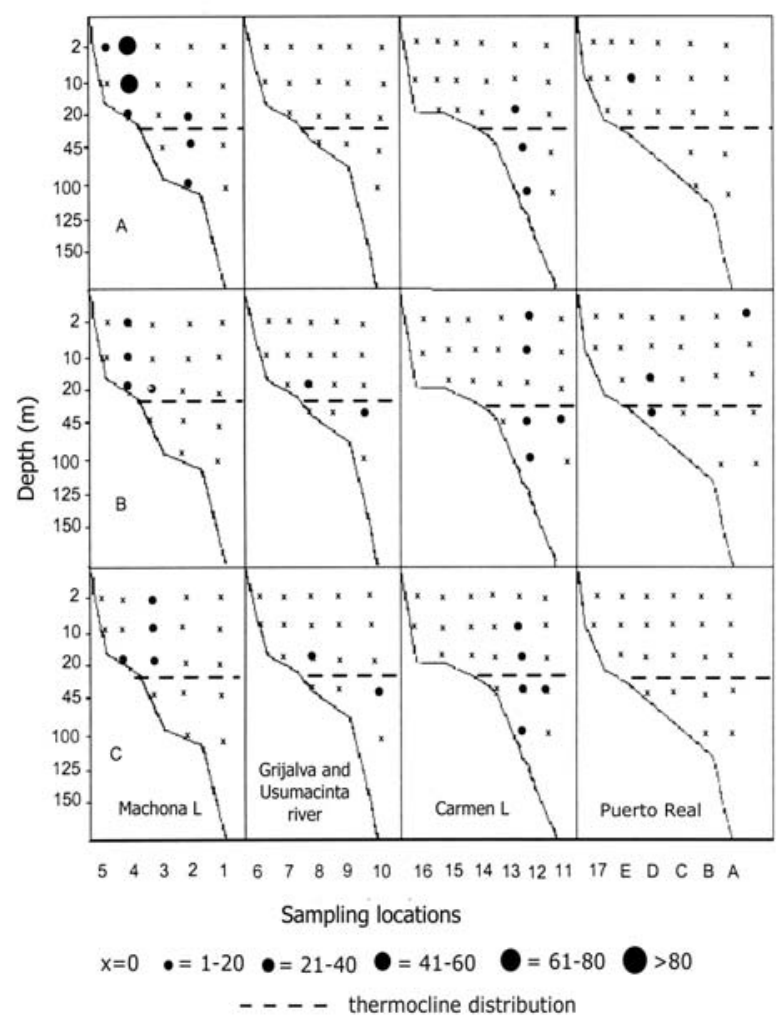

Figure 3

Solenocera larval and postlarval abundance $\left(\mathrm{N}^{\circ} 100 \mathrm{~m}^{-3}\right)$ in the different transects and depth levels. Summer 1993. A) protozoea, B) mysis and C) postlarvae

Abundancia de larvas y postlarvas de Solenocera $\left(\mathrm{N}^{\circ} 100\right.$ $\mathrm{m}^{-3}$ ) en diferente niveles de profundidad y transectos.

Verano de 1993. A) protozoea, B) mysis y C) postlarvas

and another one of 21 to 40 larvae $100 \mathrm{~m}^{-3}$ at $2 \mathrm{~m}$ depth in front of the Machona Lagoon (Fig. 4A). The largest mysis abundance was located off the Machona Lagoon at $2 \mathrm{~m}$ depth, with values of 61 to 80 larvae $100 \mathrm{~m}^{-3}$ and in front of the Términos Lagoon at 20 and $45 \mathrm{~m}$ depth with 41 to 60 larvae $100 \mathrm{~m}^{-3}$ (Fig. 4B). Postlarvae were only observed off Machona Lagoon and Grijalva Usumacinta River with low abundance (Fig. 4C). In general, protozoea and mysis stages were distributed above the thermocline, halocline, and pycnocline. Only in three stations, during the three analyzed oceanographic cruises, the larvae were found distributed below these regions. However, the abundance in these stations was very low (1 to 20 larvae $100 \mathrm{~m}^{-3}$ ). 


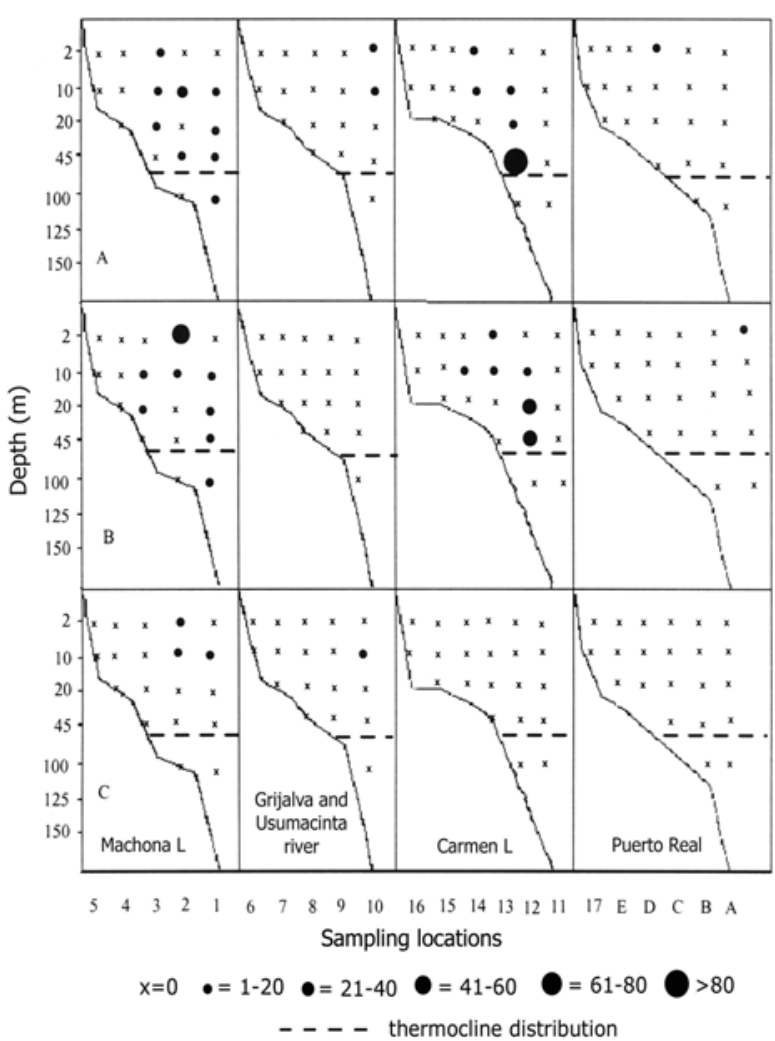

Figure 4

Solenocera larval and postlarval abundance $\left(\mathrm{N}^{\circ} 100 \mathrm{~m}^{-3}\right)$ in the different transects and depth levels. Autumn 1993.

A) protozoea, B) mysis and C) postlarvae

Abundancia de larvas y postlarvas de Solenocera $\left(\mathrm{N}^{\circ} 100 \mathrm{~m}^{-3}\right.$ ) en diferente niveles de profundidad y transectos. Otoño de 1993. A) protozoea, B) mysis y C) postlarvas
Postlarvae also seemed to show this behavior but their abundance during the three oceanographic cruises was always very low; thus, they were not representative to conclude something about the vertical distribution of this life stage (Table 2).

During the spring 1994, protozoea were caught only during night, and the greatest abundance was recorded at $10 \mathrm{~m}$ depth. Mysis were caught during the day, with the greatest abundance at $20 \mathrm{~m}$, and during the night at $100 \mathrm{~m}$. Postlarvae were collected only during the dark period, with the greatest catching percentage at $100 \mathrm{~m}$ depth (Figs. 5A, B and C).

During the summer 1993, protozoea showed a very well defined vertical pattern. In general, they were found at $20 \mathrm{~m}$ depth during the day and at $2 \mathrm{~m}$ depth during the night, and descended to $10 \mathrm{~m}$ at dawn. Mysis depicted a very similar pattern to that of protozoea, whereas postlarvae were mainly found at $20 \mathrm{~m}$ depth during the day and at $10 \mathrm{~m}$ depth at the dark hours (Fig. 6A, B and C).

Solenocera larval behavior in the autumn was opposed to that observed during the spring and summer. During autumn, larvae did not show a clear vertical migration pattern. The larval distribution in the water column was very irregular during the different periods of the day (Fig. 7A, B and C). Protozoea were collected during this season with the largest abundance at 2 and $45 \mathrm{~m}$ depth; at dusk at $45 \mathrm{~m}$, and during the night at $20 \mathrm{~m}$ (Fig. 7A). Mysis were most abundant at 2 $\mathrm{m}$ during the day, at $20 \mathrm{~m}$ at dusk, and between 10 and $20 \mathrm{~m}$ depth during the night. Postlarvae presented their highest abundance during the day at $10 \mathrm{~m}$, and during dusk at $20 \mathrm{~m}$ depth (Fig. 7B and C).

Table 2

Statistical analysis of Solenocera spp. developmental stages density in relation to the distribution of the thermocline

Análisis estadístico de la densidad de los estadios del desarrollo de Solenocera spp. en relación con la distribución de la termoclina

\begin{tabular}{cccc}
\hline Stage & t observed & t from tables & $P$ value \\
\hline Protozoea & 2.40 & 1.89 & $0.025<P<0.01$ \\
Mysis & 1.92 & 1.86 & $0.05<P<0.025$ \\
Postlarva & 1.54 & 1.89 & $P<0.05$ \\
\hline
\end{tabular}




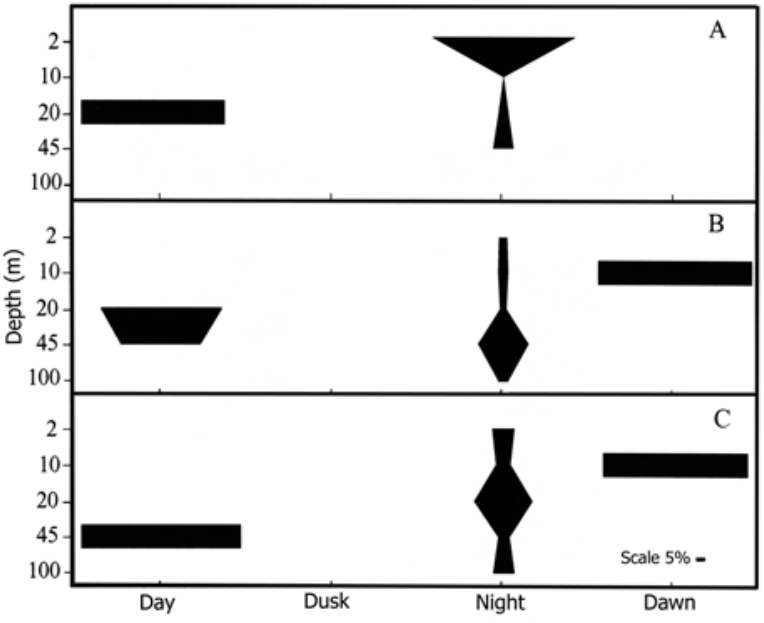

Figure 5

Vertical distribution patterns of Solenocera at different light-intensity periods during spring 1994. A) protozoea, B) mysis and C) postlarvae. (scale $5 \mathrm{~mm}=5 \%$ )

Patrones de distribución vertical en diferentes periodos de intensidades de luz durante la primavera de 1994. A) protozoea, B) mysis y C) postlarvae. (escala $5 \mathrm{~mm} \mathrm{=} 5 \%$ )

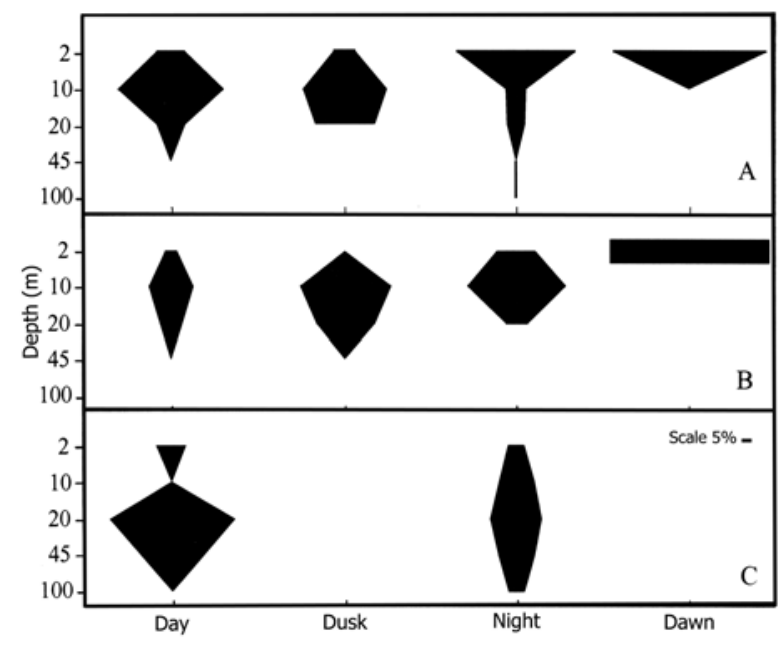

Figure 6

Vertical distribution patterns of Solenocera at different light-intensity periods during summer 1993. A) protozoea,

B) mysis and C) postlarvae. (scale $5 \mathrm{~mm}=5 \%$ )

Patrones de distribución vertical en diferentes periodos de intensidades de luz durante el verano de 1993. A) protozoea, B) mysis y C) postlarvae. (escala $5 \mathrm{~mm}=5 \%$ )

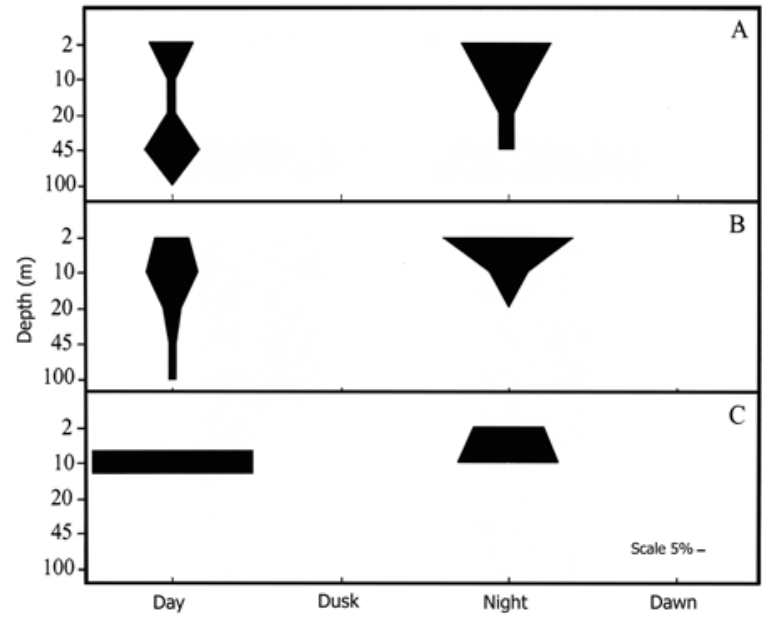

Figure 7

Vertical distribution patterns of Solenocera at different light-intensity periods during autumn 1993. A) protozoea, B) mysis and C) postlarvae. (scale $5 \mathrm{~mm}=5 \%$ )

Patrones de distribución vertical en diferentes periodos de intensidades de luz durante el otoño de 1993. A) protozoea, B) mysis y C) postlarvae. (escala $5 \mathrm{~mm}=5 \%$ )

\section{Discussion}

The main concentration of protozoea during the spring was found in front of the Tabasco shelf, near the coast line of the Machona Lagoon between 2 and $10 \mathrm{~m}$ depth (Fig. 2A). These larvae probably were hatched from small spawning populations distributed in front of the Machona Lagoon (Vázquez-Bader 1988). On the other hand, mysis and postlarval stages were found distributed with low abundances in a large portion of the area from 2 to $100 \mathrm{~m}$ depth. Older larval stages have potential for greater vertical migrations and longer exposure to the currents. Due to the greater movement of these stages as compared to protozoea (Jones et al. 1970), they are widespread in the study area. Mysis dispersal could be increased by current advection during vertical migration.

Protozoeae were distributed throughout the water column with a general tendency to find the highest concentrations near surface levels. Early larvae were also found near the bottom where they hatched from demersal eggs and then had a vertical migration. The larger abundance of protozoea and mysis in front of 
Términos Lagoon during summer and autumn agrees with the idea of a circular larval movement pattern for retention and recruitment to adult Solenocera population proposed by Gómez-Ponce \& Gracia (2003). The largest proportion of females in this area had been recorded during summer (Vázquez-Bader \& Gracia 1994, Gómez-Ponce \& Gracia 2003), which coincides with high abundance of first larval stages of Solenocera. On the other hand, during summer, an increase in phytoplankton abundance occurs (up to 6.3 millions of cells $\mathrm{L}^{-1}$ (Licea \& Luna 1999). The vertical variation of phytoplankton abundance showed high values between the surface and $20 \mathrm{~m}$ depth (Licea \& Luna 1999), and consequently, an increase in zooplankton biomass in this depth was also found (Flores-Coto et al. 1988, 1993). This is associated with the large amount of organic matter supplied by the river plumes as a consequence of the high pluvial rates observed during rainy season (Shirasago 1991). Larger available food could enhance larval survival probabilities and favor recruitment success from larval/postlarval stage to the adult phase. Greater primary productivity may favor a peak of Solenocera reproductive activity during the summer-autumn rainy season. Widespread distribution of postlarvae during summer indicates that recruitment process to the adult population occurs mainly at mid outer shelf in front El Carmen during this season. During the winter, movements of postlarval populations to greater depths have been frequently observed associated with the recruitment process to the adult population, which is largely distributed between 50 and $100 \mathrm{~m}$ depths (Vázquez-Bader 1988). Gómez-Ponce \& Gracia (2003) suggest that this recruitment can be part of the main reproductive period that could extend over various months like in other tropical peneids (Gracia et al. 1997, Sandoval Quintero \& Gracia 1998).

Solenocera larvae depicted the typical day vertical migration pattern that varied with the season of the year and the larval stage. It was possible to observe a migrating behavior during the spring and summer seasons in which larvae tended to concentrate at deeper sites during the light-hours, whereas during the darkhours, larvae moved towards the surface; similar results were reported by Ringelberg (1995). These results agree with those found by Jones et al. (1970), Rothlisberg (1982) and Rothlisberg et al. (1983), who stated that the largest proportion of larval stages of organisms from the Penaeidae family distribute themselves towards the surface during the night and close to the bottom during the day; since younger larvae tend to distribute in the surface water layers and the older ones in the deeper strata. During the autumn 1993 (November), larvae did not present a clearly defined vertical migration pattern as they distributed indistinctly at different depths, independently from the light period. Temple \& Fisher (1965), in a study near Galveston, Texas, observed a similar behavior in peneids. In that study, they mentioned that given the environmental conditions affected by strong wind season (called "Nortes"), the mixing zone becomes deeper and consequently the thermocline is displaced to greater depths, or is not formed at all, resulting in the absence of a defined vertical migration pattern.

It has been observed that often the vertical movements of larvae start before light intensity changes. In other cases, the reference factor could be temperature, thus the migration pattern is not observed if temperature is uniformly distributed through the mixed water column (Sastry 1983a, 1983b). In this sense, the thermocline seems to mark a division or physical barrier, as suggested by the results from the Student's t test applied to the spring season in this study (Table 2). The thermocline could be a barrier for the younger Solenocera stages (protozoea and mysis), a phenomenon that has also been proposed by Criales \& Lee (1995) and Lougee et al. (2002). However food availability in the upper layers could be a more determinant factor for Solenocera larvae distribution at these layers.

Vertical migration could be modified by the horizontal current movements of the water layers through the water column, i.e., the up and down migrations of the Solenocera larvae allow them to be transported to potential habitats for their dispersal and colonization. Migration has also been interpreted as a defense mechanism against visual predators; in the sense that during the daylight hours these organisms can be easy preys for predators: larvae move to deeper sites to avoid this predation pressure (Gault 1953, Zaret \& Suffern 1976, Rothlisberg 1982, Rothlisberg et al. 1983, Hessen \& Rukke 2000, Bo-ping \& Straskraba 2001, Eiane \& Parisi 2001). In this case most of the Solenocera larvae seem to remain in the $20 \mathrm{~m}$ upper layer during mysis and protozoea stages where food availability could play a more determinant role. 


\section{Literature cited}

Bo-ping H \& M Straskraba. 2001. Control mechanisms of diel vertical migration: Theorethical assumptions. Journal of Theoretical Biology 210: 305-318.

Burkenroad MD. 1939. Further observations on Penaeidae of the northern Gulf of Mexico. Bingham Oceanographic Collection 6(6): 1-62.

Cook H. 1966. Clave genérica para la identificación de protozoeas, mysis y fases postlarvarias de Peneidos litorales del Noroeste del Golfo de México. Fishery Bulletin 65(2): 437-447.

Criales MM \& TN Lee. 1995. Larval distribution and transport of penaeoid shrimp during the presence of the Tortugas Gyre in May-June 1991. Fishery Bulletin 93(3): 471-482.

Eiane K \& D Parisi. 2001. Towards a robust concept for modelling zooplankton migrations. Sarsia 86: 872-886.

Flores-Coto C, L Sanvicente-Añorve, R Pineda-López \& M Rodríguez-Vannlier. 1988. Composición, distribución y abundancia ictioplanctónica del sur del Golfo de México. Universidad y Ciencia 5(9): 65-84.

Flores-Coto C, F Zavala-García \& G Espinosa-Villagrán. 1993. Asociaciones ictioplantónicas de la bahía de Campeche, México (verano, 1987). Universidad de Cataluña del Norte de Coquimbo. Serie Ocasional 2: $57-$ 60 .

Gault DT. 1953. Diurnal variations in the grazing of planktonic copepods. Journal of the Marine Biological Association of the United Kingdom 31: 461-474.

Gomez-Ponce MA \& A Gracia. 2003. Distribution and abundance of larvae and adults of Solenocera (Decapoda, Solenoceridae) in the Southwestern Gulf of Mexico. Crustaceana 76(6): 681-698.

Gracia A, AR Vázquez-Bader, F Arreguín-Sánchez, LE Schultz-Ruiz \& JA Sánchez. 1997. Ecología de camarones peneidos. En: Flores D, P Sánchez-Gil, JC Seijo \& F Arreguín-Sánchez (eds), Análisis y diagnóstico de los recursos pesqueros críticos del Golfo de México. pp. 127-144. Universidad Autónoma de Campeche, Epomex, Serie Científica.

Jones AC, DE Dimitriou, JJ Ewald \& JH Tweedy. 1970. Distribution of early developmental stages of pink shrimp, Penaeus duorarum, in Florida water. Bulletin of Marine Science 20: 634-661.
Hessen DO \& NA Rukke. 2000. Size-dependent visual predation risk and the timing of vertical migration in zooplankton. Limnology and Oceanography 45(8): 18381844.

Licea S \& R Luna. 1999. Spatio-temporal variation of phytoplankton on the continental margin in the SW Gulf of Mexico. Revista de la Sociedad Mexicana de Historia Natural 49: 89-99.

Lougee A, M Bollens \& $\mathbf{R}$ Avent. 2002. The effects of haloclines on the vertical distribution and migration of zooplankton. Journal of Experimental Marine Biology and Ecology 278: 111-134.

Ringelberg J. 1995. An account of a preliminary mechanistic model of swimming behavior in Daphnia: its use in understanding diel vertical migration. Hydrobiologia 307: 161-165.

Rothlisberg PC. 1982. Vertical migration and its effects on dispersal of penaeid shrimp larvae in the Gulf of Carpentaria, Australia. Fishery Bulletin 80: 541-554.

Rothlisberg PC, CJ Jackson \& RC Pendrey. 1983. Specific identification and assessment of distribution and abundance of early penaeid shrimp larvae in the Gulf of Carpentaria, Australia. Biological Bulletin 164: 279-298.

Sandoval-Quintero ME \& A Gracia. 1998. Stages of gonadal development in the spotted pink shrimp Penaeus brasiliensis. Journal of Crustacean Biology 18(4): 680685.

Sastry AN. 1983a. Pelagic larval ecology and development. In: Bliss ED (ed). The biology of Crustacea 7: 213-269. The American Museum of Natural History. Academic Press, New York.

Sastry AN. 1983b. Ecological aspects of reproduction. In: Bliss ED (ed). The biology of Crustacea 7: 178-225. The American Museum of Natural History. Academic Press, New York.

Shirasago GB. 1991. Hidrografia y análisis frontogenético en el sur de la bahía de Campeche. Proyecto de Especialización, Maestría y Doctorado en Ciencias del Mar, Unidad Académica de los Ciclos Profesionales y de Posgrado, Colegio de Ciencias y Humanidades, Universidad Nacional Autónoma de México, México, 141 pp.

Smith PE \& SL Richardson. 1977. Standard techniques for pelagic fish egg and larvae surveys. FAO Fisheries Technical Paper 175, 100 pp. 
Subrahmanyam C. 1971. Shrimp larvae (Family Penaeidae) of the Mississippi Coast. Gulf Research Report 3(2): 241258.

Temple RF \& CC Fisher. 1965. Vertical distribution of planktonic stages of penaeid shrimp (Penaeus spp.) in the northwest Gulf of Mexico. Fishery Bulletin 60: 323-334.

Vázquez-Bader AR. 1988. Comunidades de macroinvertebrados bénticos de la plataforma continental del suroeste del Golfo de México. Tesis de Doctorado en Ciencias del Mar, Unidad Académica de los Ciclos Profesionales y de Posgrado, Colegio de Ciencias y
Humanidades, Universidad Nacional Autónoma de México, México, 152 pp.

Vázquez-Bader AR \& A Gracia. 1994. Macroinvertebrados bénticos de la plataforma continental del suroeste del Golfo de México. Instituto de Biología. Universidad Nacional Autónoma de México. Publicación Especial 12, 113 pp.

Zaret TM \& JS Suffern. 1976. Vertical migration in zooplankton as a predator avoidance mechanism. Limnology and Oceanography 21: 804-813.

Recibido el 30 de octubre de 2006 y aceptado el 20 de marzo de 2007 